\title{
Organisational Restructuring, Knowledge and Spatial Scale: \\ The Case of the U.S. Department Store Industry
}

\begin{abstract}
Recent economic geography literature has underlined the role of tacit/local knowledge in embedding firms within their locales, characterised by the work on "learning regions", "territorial embeddedness", "institutional thickness" and "new industrial spaces". This paper contributes to this theoretical debate, using evidence from organisational restructuring of the U.S. department store industry to argue that, in contrast, retailers are using codified/universal knowledge, supported by tacit/local knowledge to successfully operate their retail operations across a range of spatial scales. As such, no one form of knowledge is exclusively relied upon but rather a blend of knowledges reduces costs and increases responsiveness across space.
\end{abstract}

Keywords: organisational restructuring, scale, retail, knowledge

\author{
Steve Wood \\ Department of Geography, University of Southampton, SO17 1BJ \\ Email: S.M.Wood@soton.ac.uk
}

Prepared for forthcoming special issue of Tijdschrift voor Econmische en Sociale Geographie on New Geographies of Retailing, edited by Sallie Marston and Neil Wrigley, Vol. 92, No. 3

'The development of the spatial form of the organization cannot be divorced from the environment within which it operates' Milford Green, 1990, p24.

\section{INTRODUCTION}

In recent years the study of retail geography as a sub-discipline of economic geography has seen something of a renaissance. Geographers have moved away from traditional concerns focused solely on retail location, instead taking new and innovative approaches (see Crewe, 2000; Lowe and Wrigley, 1996 for reviews). Indeed, the 'new' retail geography, as christened by Wrigley and Lowe (1996, see also 2001), with its close linkages to wider theoretical perspectives on consumption spaces and commercial culture across the social sciences (see Jackson et $a l ., 2000$ ), finds itself on the cutting edge of debates about the nature of contemporary society. As Hallsworth and Taylor (1996) suggest, the 'new' retail geography is a bold attempt to

...break free from the conception of retail studies as a minor subset of economic geography situated around retail logistics: an approach that has frequently been characterised by studies of retail catchment areas or models of store sales performance. The new retail geography is characterised by a more critical theoretical approach, driven by a recognition of the significance of factors of consumption as well as of production (p2125).

In essence, since the early 1990s there has been a reconstitution and repositioning of the subject within a wider multi-disciplinary 'hot-bed' of research. This reconstitution and repositioning has resulted in both cultural and economic readings of retail industry.

The new economic geography of retailing has produced a diverse array of work concerned with the transformation of retail capital and its geographical expression (see Lowe and Wrigley, 1996). A number of themes have achieved prominence, particularly the reconfiguration of corporate structures (Sparks, 1995; Wrigley, 1998a; 1999a; 1999b) 
and the consequent restructuring of retailer-supplier interfaces (Doel, 1999; Hughes, 1999). Research incorporating these themes has increasingly taken the organisational and technological transformations of retail distribution and logistics seriously (Fernie, 1994; Sparks, 1994) and frequently analysed the social relations of production and labour relations in retailing (Christopherson, 1996; Freathy and Sparks, 1996). Over time, this literature has reviewed the role of retail restructuring in prompting the switching of retail capital, whether it be to alternative formats of distribution (Burt and Sparks, 1993; Fernie and Fernie, 1997), or alternative spaces in a national or international context (Shackleton, 1998; Wrigley, 2000a; 2000b). And in its turn, the spatial switching of retail capital is recognised to be influenced by regulation, whether this is through state restrictions on store location (Guy, 1998; Wrigley, 1998b), competition and consolidation (Wrigley, 1992; 2000c), or the role of the retailer in policing food safety (Marsden et al., 2000; Marsden and Wrigley, 1995).

More broadly the 'cultural turn' characteristic of recent work in the social sciences has seen the new retail geography inflected with knowledges from a wide array of disciplines. Linkages have been forged with scholars in anthropology, cultural studies, sociology and cultural history (e.g. Jackson et al., 2000; Miller et al., 1998), as the subject has been positioned within the broader body of work in the humanities on consumption spaces and culture both historical and contemporary (see Abelson, 1989; Mort, 1996; Miller, 1998; 2000; Nava, 1996). Historical accounts have often focused on late $19^{\text {th }}$ Century and early $20^{\text {th }}$ Century spaces of consumption - notably the department store (see for example Blomley's (1996) reading of Emile Zola's Au Bonheur des Dames and Domosh's (1996a) reading of the retail landscape of late $19^{\text {th }}$ Century New York). More contemporary accounts have investigated particular consumption spaces and places such as the shopping mall and car boot sale (see Hopkins, 1990; Goss, 1993; 1999; Gregson et al., 1997; Shields, 1992; M. Smith, 1996). Themes arising from contemporary consumption have been assessed through theoretical analyses of the cultural politics of contemporary advertising (Jackson and Taylor, 1996) and analysis of associated gender identities (see Jackson, 1993; Jackson and Holbrook, 1995). It is this eclectic perspective of economic and cultural aspects of retailing that have widened the appeal and relevance of the sub-discipline

This paper attempts to blend both of these economic and cultural conceptions of retailing to tackle an emerging debate within economic geography on the relationship between knowledge and spatial organisation. These issues particularly concern the battle between the role of tacit knowledge at the local level and codified knowledge at central nodes within the firm and their subsequent geographical expression. Interestingly, the new retail geography has been almost completely silent about the interplay between retail, knowledge and geography. The few contributions that have emerged tend to focus on the role of networks, cultures and commodity chains (Hughes, 2000; Leslie and Reimer, 1999) rather than the implications for the spatial organisation of the firm.

The U.S. department store industry has considerable potential to illuminate these theoretical debates on situated and universal knowledge in firms ${ }^{63}$. The sector has only been partially analysed in the literature of the new retail geography - essentially from a historical/cultural perspective (Crossick and Jaumain, 1999; Domosh, 1996b; Dowling, 1993; Nava, 1996; Reekie, 1993). In particular its economic geography has rarely been studied, the few exceptions being contributions from the 1980s (Bluestone et al., 1981; Laulajainen, 1987; 1988; 1990). Moreover, recent studies of the department store in the management literature have essentially disregarded the U.S. sector (see Gold and Woodliffe, 2000; McPherson, 1998; Phillips et al., 1992). In contrast, this paper focuses specifically on the U.S. industry to make a contribution both to the missing debate within the new retail geography on the relationship between the use and interpretation of commercial knowledge and its relation to the geographical organisation of the firm, and also to the economic geographies of this important sector of retailing during the 1990s.

\section{GEOGRAPHIES OF KNOWLEDGE AND DISTANCE}

The relationship between geography and knowledge is a complex one, subject to conflicting opinions in the literature of economic geography. One perspective suggests that the burgeoning of integrative information and communication technologies result in a disembedding of economic activity. Such interlinkages are viewed as heralding an economy where geography is of less importance (see O'Brien, 1992). As such, "expert systems" have separated space and time and had the effect of disembedding social systems (Giddens, 1991).

\footnotetext{
${ }^{63}$ This research is based on two extensive periods of US fieldwork during January and March/April 2000, consisting of over 30 interviews with leading industry executives at department store retailers including Bloomingdale's, Saks Incorporated, and Macy's, academics, and equity analysts at Goldman Sachs, Merrill Lynch and Schroders. This material was triangulated with industry reports, press releases and the retail press. Interview quotations are numbered to protect the anonymity of respondents where this was requested.
} 
In direct response to the suggestions that place has become unimportant, a second perspective emphasises the role of local characteristics and the specificities of place that, in some instances, remain superior to the flattening effect of the integrative technologies (for example, those that drive successful financial centres, Martin, 1994; Porteous, 1999; Thrift, 1994). These characteristics and specificities have often been discussed in work which suggests the rise of new industrial spaces and the ties of tacit knowledge that bind them, characteristic of the literature of postFordism (Henry and Pinch, 2000; Storper, 1997; Storper and Salais, 1997). These 'learning regions', rich in territorial embeddedness, and institutional thickness (cf. Amin and Thrift, 1994) have often been used as models or caricatures of 'cultural embeddedness' (Zukin and Dimaggio, 1990) to which examples are sought to fit (Yeung, 2000a). In such formulations space is characterised as 'slippery', whilst place is 'sticky' to attract a spatial fix of capital in distinct locales (Markusen, 1996; cf. Harvey, 1982). Following from these literatures, there has been the rise of a renewed emphasis on regionalism (e.g. Lovering, 1999) and 'learning economies' (see French, 1999 for a review).

Within the context of the second perspective, a more holistic and eclectic view of the firm can be developed - one which recognises the embeddedness of economic and social action in place through business networks (Yeung, 1994; 2000b). Such views partially overcome the reductionist "theory of the firm" as "(a)lmost every economist now recognizes that the firm is more than a processor of information and efficient manager of transaction costs' (Amin and Thrift, 2000, p6; also cf. Walker, 1989). A network approach thus allows concepts of knowledge and sociality to come to the fore in the research programmes of economic geography, whilst retaining the recognition of macro-structural influences (see Yeung, 1994). The network approach contrasts with the approach evident in the 'geographical economics' coming out of mainstream economics (e.g. Krugman, 1998) that is hesitant to embrace these culturally informed notions to explain the spatial organisation and agglomeration of economic activity (Martin, 1999).

The economic geography of the late 1990s, demonstrated an understanding of the importance of both codified and tacit knowledge as a major influence on the geography of organisation. As such, some networks are relatively more localised 'because they are dependent on the traded and untraded interdependencies of geographical agglomeration achieved through territorial embeddedness', whilst other networks 'are controlled "at a distance" when the key actors are spatially distanciated from the sites where the empirical events happen. In all cases, however, a specific spatial configuration is created and connected to other configurations at smaller and larger geographical scales' (Yeung, 2000a, p23-24). It is these geographies of knowledge that, to an extent, have driven the spatialities of the department store industry which forms the focus of this paper. As Henry Yeung (2000a) recently suggested, territory and scale matter because they shape the constitution of the firm through their geographical effects on social actors and their network relations. Understanding the effects of these geographies of knowledge in driving these changes is essential to understanding the nature of the firm.

The example of the organisational restructuring of the department store industry provides evidence of networks of knowledge operating at a number of spatial scales, integrating to form a successful business operation. As Schoenberger (1999) suggests, different 'places' in the firm develop organisationally and geographically, with their own identities and ways of doing things. As such, the large firm is 'internally regionalised', where the corporate form transforms a number of knowledges between different spaces. Following Amin and Cohendet (1999), this paper finds that no one form of knowledge is exclusively relied upon. Instead, the firm mediates between a number a different spatial scales, across different operations and places resulting in a dual organisational structure whereby there is firstly, a highly integrated, network organisation driving the core competencies of the organization, and secondly, a hierarchical, divisional organisation that lies beyond the core competencies of the firm (Amin and Cohendet, 1999, p94).

\section{ORGANISATIONAL RESTRUCTURING OF THE US DEPARTMENT STORE INDUSTRY}

This paper focuses on the organisational restructuring of the U.S. department store industry during the 1990s. It centres on the renegotiation of spatial scales of organisation and rerouting of knowledges through new systems of operation. By the late 1990s, the department store sector was highly centralised, concentrated in a small number of influential firms (see table 1), which had been formed as a result of the 1980s financial re-engineering and the subsequent round of strategic consolidation wave of the 1990s.

The mid-late 1980s was characterised by department store financial restructuring, as the leading chains, including Federated, Macy's and Allied, were acquired in over-leveraged deals and found themselves in bankruptcy by the early 1990s (Hallsworth, 1001; Rothchild, 1991; Trachtenberg, 1996). In contrast, the 1990s was a period of renewed consolidation activity in the sector, where emphasis moved away from highly leveraged acquisitions supported by little equity, to strategic mergers to expand market share. These consolidations were catalysed by the minimal net growth in the conventional department store sector due to intense competition from discount stores such 
as Wal-Mart and Target, and speciality stores such as Gap and Limited (Morganosky, 1997; Swinyard, 1997). In this way Federated acquired the bankrupt Macy's in 1994, and then the struggling Broadway Stores a year later, whilst Proffitt's consolidated many of the southern, regional department store chains (see table 2).

\section{The Need to Renegotiate Scale in the 1990s}

With their rapidly growing store portfolios, the major department store operators were faced with the task of rationalising and streamlining their organisational structures. In the past, U.S. department stores had operated as many as 15 divisions, each with its own buying, accounting, credit and distribution facilities. The high costs that resulted made the format increasingly uncompetitive vis a vis discount and speciality stores, which had made considerable investments in centralising their large organisations and cutting overheads (Christopherson, 1996). Department store companies simply had too many decentralised divisions with too many buyers, hampered by a bureaucratic decision-making process, often lacking a central theme. In addition, and particularly in the case of larger companies, there was a lack of information flow through the retailer-supplier interface due to a dearth of coordinated systems with consequent difficulties executing key trends across divisions (see Biederman, 1991).

Prior to the 1990s, department store firms were unable to operate in a centralised manner due to the spatial variations in demand surpassing any ability of organisational and technological interlinkage across space. As such, there was an emphasis on tacit/local market knowledge, above any centralising tendency, as markets were regarded as complex, 'each one differing from the other and for that matter having differences between themselves', whereby a 'knowledge of the makeup of these markets' was perceived as being 'essential for the most effective marketing' (Clark et al., 1926, p252). It is for these reasons that prior to the development of complex technological infrastructures, knowledge was acquired and decisions made largely at the divisional decentralised spatial scale (see figure 1):

If we...agree that the economic problem of society is mainly one of rapid adaptation to changes in particular circumstances of time and place...decisions must be left to people who are familiar with these circumstances, who know directly of the relevant changes and of the resources immediately available to meet them. We cannot expect that this problem will be solved by first communicating all this knowledge to a central board which, after integrating all knowledge, issues its orders. We must solve it by some form of decentralization (Hayek, 1945, p524, cited by Jensen and Meckling, 1992, p252).

The late 1980s however saw the emergence of much-improved technological retail infrastructures and channels of communication that had the potential to overcome the costly duplication of the top management, merchandising and back office services (Abernathy et al., 1999). These "expert systems" therefore offered the opportunity for realisation in the 1990s of what had been hypothesised for the sector in the 1920s, i.e. that the department store could 'combine the merits of centralized control which underlines the chain idea, and the decentralization of the department store' (Griffen et al., 1928, p23). It is this tension between local/tacit knowledge and universal/codified knowledge in shaping geographies of organisation that provide the focus of this paper.

\section{THE STRATEGIC ROLE OF TECHNOLOGY IN RETAILING}

As Thrift (1985) noted all knowledge is time and space specific. This fact severely constrains the interpretation of information "at a distance" from economic activity where the knowledge is produced. For this reason, amongst others, the geography of U.S. department store retailing had become a highly decentralised activity. Merchants were locally embedded within their core markets, knew them well, and performed ably. The emphasis was on responding to tacit knowledge, or, what Thrift (1985) refers to as 'practical knowledge', as it is 'produced and reproduced in mutual interaction that relies on the presence of other human beings on a direct, face-to-face basis. Such knowledge is deeply imbued with both historical and geographical specificity, taking its cues from local conditions' (p373, my emphasis). The high costs of operating in such a decentralised fashion were not considered because there was no alternative. During the 1990s, however, Giddens' (1991) 'expert systems' have revolutionised the operational geography of retailing throughout the Western world. In many respects this has permitted the consolidation wave in the department store industry, as synergistic benefits are available to large firms taking advantage of technological systems, allowing the distribution system to react more rapidly and effectively to market needs and wants.

\section{The Role of Expert Systems}

Capital centralisation throughout the U.S. retail industry has been promoted by the use of technological systems. These systems offer the potential to reduce lead times and centralise order fulfilment "at a distance". To an extent 
this new capacity eliminates the trade off between the contravening tendencies of economies of scale and sensitivity of local markets (Aufreiter et al., 1993). It also signals an increasing dependence on codified or empirical knowledge: 'distanciated, that is...removed in both time and space from the experiences and events it describes. Empirical knowledge does not depend for its acquisition on the presence of people, but it is transmitted through institutions and technologies which allow personal contact to be either by-passed or made specific to particular packets of information' (Thrift, 1985, p375-6). As Hippel (1999) suggests, firms may reduce the "stickiness" of knowledge by investing in technical expertise which converts tacit expertise to empirical or explicit knowledge through an easily transferable form of software "expert system". In grocery retailing this has represented "an important shift from an earlier pattern in which the store managers played an important role in local merchandising decisions' (Bowlby et al., 1992, p144-145; Burt, 2000; Smith, 1988; Sparks, 1994).

Electronic Data Interchange (EDI) has been at the forefront of retail innovations, enabling the inventory pipeline to move goods more swiftly between the manufacturer and the retailer. This 1980 s innovation allowed communication between the retailer, vendor and manufacturer, concerning orders and demands. This innovation was executed via a network linkage between the retail point of sale terminal (POS) on the cash register, backward through the supply chain to the warehouse, and often the manufacturer, communicating sales data and thus demands (Fernie, 1994). With this more centralised administration of sales information, came the development of distribution centres, to which vendors and manufacturers could deliver case pack merchandise leaving the retailer to deliver to stores (Smith and Sparks, 1993). In the U.S. context, Wal*Mart is widely known to be the innovator of this form of cost cutting (see Vance and Scott, 1994). Such a strategy however relies on all the merchandise being easily scanned, interpreted and integrated into the expert systems. This requirement has been facilitated through the development of Universal Product Codes (UPCs) or "bar codes", which appeared in 1970 as a ten digit, non-descriptive, all-numeric code; the leading five digits were to identify the manufacturer, the trailing five digits the merchandise item (Abarnathy et al., 1999). The UPC provided a universal medium whereby merchandise could be instantly identified and inputted into, and between, the expert systems with ease.

With a more networked supply chain, there was the potential for sales based ordering (SBO) where the supply of goods in store is driven by consumer purchases (see Fiorito et al., 1995). A networked infrastructure has allowed Quick Response (QR) in retail distribution whereby 'the time between the sale and the replacement of goods on the retailer's shelf can decrease markedly; and retail inventories can be maintained at all levels which will meet consumers' demands' (Fiorito et al., 1995, p 12). QR was a concept developed in 1985 by major U.S. retailers, their suppliers and IBM. The goal was to reduce inventories, increase on-sales, customer satisfaction and profits through faster and more frequent shipments. Computer links between the store, vendor and manufacturer shortened the time between a purchase by the consumer and the re-manufacturing, distribution and re-stocking of that same product in the same store (see Fernie, 1994). These EDI transactions are delivered via private, dedicated communication networks called Value Added Networks (VAN) or Intranets (see American Apparel Producers Network, 1999 for a summary).

Although QR was initiated by U.S. retailers, it was the U.K. food industry which developed and refined the system during the late 1980 s - to an extent that by the mid 1990s the U.S. grocery retailers lagged up to 10 years behind the U.K (Wrigley, 1998c). These technological evolutions were initially adopted in the food industry because distribution is somewhat easier with basic, rapid inventory-turn merchandise. The infiltration of a quick response perspective has been slower in the department store industry, as the merchandise is considerably more expensive and involves considerably greater sunk cost and unpredictable demand. Furthermore, whilst retailers of basic merchandise are keen to project a consistent image and are thus more conducive to centralisation (Burt, 2000, p882), department store retailers often run a number of chains in different areas, each with their own regional identity and market positioning. Indeed, retailers differ in their applicability to new technologies as; '(m)ost large retailers are complex organizations that differ in degrees of centralization and formalization. How these organizational differences influence retailer buying behaviour remains unknown...' (Hansen and Skytte, 1998, p296). The organisational adaptation of department store retailers to these technological developments is now discussed through a case study of the speciality department store, Saks Fifth Avenue.

\section{CASE 1 - THE EVOLUTION OF THE SAKS FIFTH AVENUE SUPPLY CHAIN}

Saks Fifth Avenue is an upscale speciality department store with 61 stores across affluent cities of the United States. In 1998 it was acquired by Proffitt's, Inc., but since then has been run largely as an independent operating concern. This case study analyses how the supply chain of the firm has reacted to the revolutions in the relationship between knowledge and geography throughout the 1990s. 
Figure 2 displays the quick response system of Saks Fifth Avenue, interlinking the retailer, vendor and distribution centre through the new technologies. Buyers in New York City receive sales data from the network of stores and undertake all of the ordering centrally. A purchase order is entered by the buyer or created by the Basic Automatic Replenishment Computer Model (BAR) for each store, according to each specific product line or Stock Keeping Unit (SKU), and sent to the vendor via Electronic Data Interchange (EDI). After 3-10 days, the vendor packs the merchandise. Prior to it being prepared for distribution to the distribution centre (DC), an Advanced Shipment Notice (ASN) is sent to the buyer in New York and the DC, again via EDI, to tell them it is soon to arrive. On arrival at the DC, the merchandise is immediately identified as it is coded with a Universal Product Code so it is clear to which store it is to be sent. Consequently, the merchandise does not have to remain in storage at the distribution centre. It is typically placed straight onto a truck destined for the store in a process known as "crossdocking" (Abernathy et al., 1999). The quicker products can arrive in the store, the sooner they can be sold and the less time capital is tied up in inventory and can be invested in other merchandise (cf. Chandler, 1990).

\section{The Conflict of Knowledge: Codified or Tacit?}

The purchase order is determined through two different techniques. Firstly, there is the dynamic system, where sales data is fed into a computer system that analyses the information in terms of the "peaks and valleys" of historical sales performance and makes predictions of future demand. The buyer then confirms or adjusts the order, based on a number of factors including changes in the store capacity, or his/her tacit knowledge of the market or weather conditions, and sends the order. Alternatively, there is utilisation of the automatic replenishment model. Products that are ordered regularly are candidates for automatic replenishment based on sales information interpreted through "expert systems" without express input from the buyer. Basic merchandise is particularly applicable to this form of ordering as it is typically characterised by rapid turnover and predictable demand (see table $\mathbf{3}$ ).

The extent to which basic merchandise can be put on automatic replenishment, and not ordered manually by the buyers, has become a contested issue within these organisations. As Schoenberger $(1994 ; 1997)$ has shown in a number of publications, individuals pursue self-interest in the firm, which may not necessarily be congruent with the strategic goals of the firm. Buyers are hesitant to give up control of a portion of their budget as this diminishes their responsibility within the organisation. This is in contrast to the operational logic evident in doing so. As the Director of Quick Response at Saks Fifth Avenue commented, automatic replenishment removes the emotional element that is not required for basic merchandise:

An emotional buy for a basic item - there is no emotion in basics. I mean it is white underwear - there's no emotion. It is a need. We are saying that buyers should be buying fashion, they shouldn't be buying basics. Basics: a computer can do it. You don't need a brain to do it. You don't need a taste level. It's black and white and that's it, but fashion is what we are training the buyers to be (Interview 2).

Even in areas where the buyer previously had control, the codified knowledge is conflicting with traditional tacit based knowledge. With more complex sales prediction packages, the buyers' sovereignty is threatened.

Furthermore, with the interlinked supply chain there is the potential for the retailer to cut costs and allow the vendor to drive the system if they are given access to the sales data. This is dependent however on mutual trust sharing between the two parties. It is to these concerns the paper turns.

\section{Vendor intensification}

The ability of the retailer to offset costs and allow the vendor to drive the supply chain is dependent on an increase in the intensification of the relationship between the two parties. Indeed, at the start of the 1990s McKinnon argued grocery retailers were recognising that by 'concentrating responsibility for buying at head office, retail chains can strengthen their position vis-à-vis suppliers and economise on associated administrative and clerical work' (McKinnon, 1990, p80). Such U.K. retailers have successfully centralised and dominated the supply chain in this manner with the virtual elimination of independent merchants (Wrigley, 1991; 1993), increasing leverage with suppliers evident in the rise in numbers and quality of own-label products in recent years (Doel, 1999; Hughes, 1999).

U.S. department stores have sought to centralise and change the relationship between the vendor and the retailer. Indeed, the trend more generally throughout the 1990s U.S. retail industry was 'vendor intensification' (Ernst and Young LLP, 1998). Department stores have built long-term working relationships with key vendors as an alternative to a more arms-length adversarial model (Porter, 1999). It was envisaged that building such understanding with firms lower down the supply chain would help maintain a more reliable arrival of products, reducing the costs of overstocks, unplanned markdowns, out of stocks, and customer dissatisfaction. It was expected that this closer working would facilitate risk sharing, allowing large dominant department stores to 
pressure suppliers for 'markdown money', reducing profit loss due to slow selling merchandise (Sternquist and Byoungho, 1998). Vendor intensification was made a reality through the pooling of resources that occurred with consolidation, and general closer working of the divisions through the strategic use of technology.

\section{Vendor Managed Inventory}

The use of integrative technologies themselves require a closer working relationship between the retailer and vendor/supplier, with a certain amount of trust evoked in sensitive data sharing (Maltz and Srivastava, 1997). As Evans and Wurster (1997) have recently suggested '(w)hen companies conduct business with one another, the number of parties they deal with is inversely proportional to the richness of information they need to exchange' (p17). As large companies establish market sensitive organisational structures, the boundaries between companies will become less important (see Malone and Laubacher, 1998). With retailers now dominating the supply chain, they need to realise efficiencies can result if they work collaboratively, sharing market sensitive information to more accurately respond to changes in consumer demand (Kumar, 1996). This gradual move to a closer working relationship is starting to be seen in the supply chains of UK food retailing (Doel, 1999) and the UK apparel sector (Crewe and Davenport, 1992), where, if trust can be established, a mutually beneficial networked information-rich supply chain can result (see Wall et al., 1994).

\section{Removing the Tacit Knowledge with Vendor Managed Inventory}

Saks Fifth Avenue have taken tentative steps toward vendor-managed inventory. Hitherto this has only been seen in cosmetics, with the vendor, Clinique, becoming responsible for collecting and interpreting the codified knowledge, and thus the buying of their products. The rationale for allowing Clinique to participate in vendor managed inventory is that they know their product better than any retailer would. This model of vendor managed inventory follows the pioneering progress of $\mathrm{Wal} *$ Mart, who were the first to produce such a relationship with Proctor and Gamble in the early-1990s (Moore, 1993). As mentioned, the most critical element in moving toward vendor managed inventory is establishing trust between the vendor and the retailer. As Ann Whitney, Director of Quick Response suggests:

No.1 you have to trust the vendor because he is spending your money but with that trust he also can give you the guarantee that if he gives you the wrong assortment of merchandise, or puts you into an overstocked position, that he will return that merchandise because the agreement up front is that if you give us too much, you own it - we are sending it back, and at your expense. That keeps them in line so they don't spend, they don't go crazy with our money (Interview 2).

This new vendor driven system replaces the conventional system of decentralised procurement of cosmetics for the department store retailer. Previously, ordering for cosmetics was undertaken at the branch level by individual department managers who took a stock count and ordered every week through a manual book keeping method which was very labour intensive. Supply chain specialists argue that this practice, based on local market tacit knowledge, could often result in 'emotional buys', not substantiated by sales information with personal tastes and preferences were overvalued.

\section{CASE 2 - (RE) NEGOTIATING SCALE AT FEDERATED DEPARTMENT STORES}

Federated manages a number of department store chains operating at varying price points across the U.S. (see table 4). The search for increased efficiencies in the organisational structure through centralisation started in the early 1990s, where current and newly acquired divisions were merged when they were in geographical proximity (see table 5). Such changes allowed immediate cost savings, eliminating duplication of core functions. These divisional consolidations were accompanied by a broader restructuring package exploiting economies of scale in buying but remaining sensitive to the immense geography of the trading area.

The initiatives by Federated were prompted by the substantial cost savings experienced by the May Department Store Company, which had, since the late 1980s, pursued a vigorous policy of the centralisation of resources and provision of shared services. This made its acquisitions rapidly accretive to the extent that during the 1990s it was regarded as the most efficiently run department store chain in the U.S.

\section{The Uncharted Road to Centralisation}

The trend toward centralisation has not been a smooth process, and has proven a particularly contested terrain within Federated. In 1992, Federated launched the Federated Accelerated Sales \& Stock Turn (FASST) plan as a means of 
helping the corporation and its vendors work together more effectively to manage merchandise inventories. This was the first step towards modernizing the firm with a new structure configured for the new millennium. The lynchpin of the new initiative was team buying, supplanting the previous strategy of autonomous buying by the divisions. Team buying reduced the merchandising and support staff, obtained volume discounts and established stronger relationships with fewer suppliers (Bailey, and Bernhardt, 1996). Bailey and Bernhardt (1996) suggest that, in essence, the department store was conceptualised as an umbrella for a series of merchandise categories, or as a chain of speciality stores. Merchandising was organised under a 'Family of Business Arrangement', whereby each specific commodity area (e.g. sportswear, dresses, suits) was to receive direction from a team comprised of a visual director, marketing director and a director of stores. Each 'Family of Business' was broken down into a group of classifications, which then formed the basis of teams. This formation of teams did not however change the structure of the division's merchandising organisations. The segmented nature of the organisation essentially continued to exist. At this time, teams were expected to play a role in virtually every step of the merchandising process. They were expected to develop $70 \%$ of the assortment for each division with the mandate to plan, negotiate, select and price the merchandise, and then communicate and co-ordinate these decisions with the divisions which were left to develop 30 percent of the assortment on their own. Indeed, as Harry Frenkel, Vice President of Federated Merchandising Group, suggests, such early team initiatives were to have 'representatives from each division and then the corporate person here in Federated Merchandising to come and dictate what your assortment should look like; "here are the key items of your assortment". That was the direction ...(to) leverage the vendor base. You know, if we go in as a group, we got to buy much smarter' (Interview 10).

The principal challenge was finding the right balance between central control and local autonomy. Indeed, at the time Julie Forsyth observed in Chain Store Age Executive Magazine:

Department store companies are beginning to operate more like chain store operations and less like collections of various autonomous divisions....Many divisional functions are being centralised to reduce costs and streamline operations. Department store companies are also downsizing their operations through divisional mergers and selected store closings. Through the introduction of advanced information technology, companies are now better equipped to monitor cost structures, manage merchandise profitability, and re-attract disinterested consumers (Forsyth, 1993, p29A).

Consequently, Federated were broadening the merchandising process beyond divisional lines and were successful, to an extent, in leveraging merchandising knowledge across the firm. Despite this achievement there were difficulties with the $70 \%$ centralised and $30 \%$ decentralised arrangement as it stood by the end of 1993 . Non-team members were left feeling disenfranchised and the process of getting apparel to market was too slow and cumbersome (Bailey and Bernhardt, 1996). Indeed, 'although the process of team allocation increased awareness of company-wide allocation patterns, team allocation to local stores proved to be highly ineffective because it lacked the knowledge of local markets' (Bailey and Bernhardt, 1996).

The flat performance of Federated in the recessionary years of 1992-3 caused a reassessment of the buying process. Top level executives of the firm and outside consultants, re-examined the merchandising structure, producing an alternative buying model for implementation in the fall of 1994, designed to reduce bureaucracy and more clearly define the chain of command. This revision reduced the mandatory 70/30 split of dominating control from Federated Merchandising Group, as FMG would instead provide a menu of selections of products from which the divisions could select. This arrangement maintained a consistency of selection and economies of scale, yet permitted flexibility in maintaining the divisions' own regional identities. These arrangements saw a reduction in the importance of teams, where they became increasingly advisory, avoiding effort duplication, where merchants had previously split their time between the divisions and their teams.

The need to remain sensitive to local markets and limit the cost saving though centralisation is clear. As Swinyard (1997) suggests, these innovations are rapidly changing the nature of the distribution system,

Competition, consumer changes and growing technology are converging to make micromarketing's historical attractiveness both achievable and profitable. It is a result of the flattening of the competitive landscape of the USA and is becoming a major retailer focus... Until just a few years ago retail firms were so strongly driven by distribution and operations efficiencies that chains had the same stock mix in Miami's year-round warm climate as they did in Minneapolis' cold one - winter coats and snow shovels in the autumn and swimming suits not until the spring (p251).

The reorganisation of 1994 effectively produced a model where Federated Merchandising Group supplied a matrix of core vendors from which the Federated divisions were strongly encouraged to select. As Vice President of 
Federated, Carol Sanger suggests, the merchandising group 'scouts the market and determines what everybody should look at when the divisions come in to go to market and makes some decisions based on economies of scale which make sense for us, but allow the divisions, where the customers see it, to have their own identity and that to us is ideal'. Each division retains its identity and conducts its own buying. There is recognition that there will be the need to purchase from some regional vendors outside of the universal matrix provided by FMG. This practice underlines the importance of embedding divisions in local markets and not wholly centralising. This importance of regional identity is made clear by the Vice President of FMG:

...we try to come up with the base and once again the divisions have to have some leeway because Burdines are in Florida so they need some specialised vendors to support their climate and environment - all that kind of stuff....Burdine's wants to be...'the Florida store'. It is different from Macy's which is in the mall right next door to them in Florida (Interview 10).

Equally, the Federated Merchandising Group (FMG) embed themselves within the fashion scene of New York City where all of the important vendors are based. Such proximity is essential to success in establishing the best prices and exclusive collections for their stores. Organisational restructuring is thus as much a story of territorial embeddedness and institutional thickness (cf. Amin and Thrift, 1994; Keeble et al., 1999), as it is about conflating distance through expert systems (O’Brien, 1992).

\section{Upscale and Uniqueness - Exceptions to FMG}

Changes in the configuration of the merchandising within Federated are not applicable across the whole organisation. The corporation operates a number of divisions across differing income levels (see table 4). Firstly, there is Bloomingdale's, a speciality department store, upscale, and more in competition with the likes of Saks Fifth Avenue and Neiman Marcus. At the other end of the spectrum, there is Stern's, a chain department store somewhat lower scale compared to the likes of Macy and Lazurus. As a result, it is problematic to include these stores within the broader FMG merchandising model, where the product assortments are more homogenous and targeted at the mid-scale, traditional department store chains. There remains therefore a considerable emphasis on completely independent regional divisional buying, where stores do not fit into the conventional department store model. Indeed, Federated Merchandising Group does not cater to Bloomingdale's or Stern's, as they buy completely independently focusing on upper and lower scale merchandise respectively. That said, they are incorporated into all of the Federated back-up support systems.

\section{Centralising the Back Office Facilities}

By the end of the 1990s, Federated was exhibiting a more centralised merchandising model to leverage the considerable scale of the organisation, yet at the same time, remain sensitive to the idiosycracies of geography and spatial variation. Such a tension between centralisation and decentralisation is less in evidence with the organisational restructuring of back office facilities. Federated have consolidated many behind-the-scenes operations and formed separate support services where aspatial expertise is required and assistance can be leveraged throughout the entire corporation. This has only occurred with any conviction in the 1990s (see figure 3). Terry Lundgren, President of Federated explained the rationale for the developments:

...we have a point of view that if the customer does not see it or feel it then it is an opportunity to be reduced or eliminated .... Every division used to have their own separate organisation - we don't need that anymore. Now we conceive it nationally in the east coast or west coast and move it to the various stores no matter if they are a Rich's store or a Lazurus store, a Bloomingdale's store or a Macy store...All of our technology, all of our systems, computer operations - every division used to have their own set up for that. Now there is one state of the art organisation outside of Atlanta that services all of the systems needs for our stores. One credit facility in Ohio services all of them (Interview 23).

Throughout the 1990s the role of these back-office systems has increased nationally throughout the organisation. Indeed, the changing role of Federated's Logistics and Operations (FLO) division is seen in table 6. Here the emphasis has been on divisional inclusion, as the group has become substantially more important, orchestrating a wider geographical field, more divisions and additional key responsibilities. As Deloitte and Touche reported in late 1998, prior to the support services' formation, it took Federated 3-5 days to move merchandise from its warehouses to the stores. By the end of the 1990s, because vendors tag and prepare most of their merchandise before they send it to Federated's automated distribution centres, the merchandise is on outbound trucks within a quarter of an hour. Over two thirds of the cartons they receive in their facilities each day are on the selling floor of the stores by the next morning. 
Not only has the speed of this turnaround increased, but also the accuracy. The arrival of data sharing with vendors has allowed the right product to be in the right place, at the right time. Such sharing of commercially sensitive information allows the theory of Collaborative Planning Forecasting and Replenishment (CPFR) to become a reality. Federated initially pursued this in 1998 with a handful of suppliers via the 'First at Federated' programme. By 2000, collaborative practices were in place with a number of suppliers including Liz Claiborne, Pillowtex and several apparel resourcers (Reda, 2000). The data sharing effectively results in more of the demanded products to be in place at the right time, whilst carrying less inventory. This increases stock-turn and reduces the amount of time capital tied up in unproductive stock.

\section{Re-emphasising Localisation}

Codified knowledge has revolutionised the role of the buyer in the department store setting. Previously, the buyer used to visit each store. In many cases there were separate buyers at each store level. Today, buyers remain the conceivers of the grand plan whilst the branches become the executers. The buyer now has to envisage "the buy" and the presentation in store "at a distance":

Instead of going out to the individual stores....now they put it on a document and their vision now goes onto a piece of paper. That piece of paper gets sent to store via the Intranet and the stores execute their vision. So clearly it is still the merchant who has the vision, the store is the executor. The stores embellish that execution, take it to another level, but the merchant still is the one who conceives (Peter Sachse, Director of Stores, Macy's East, Interview 19).

Very few of the buyers will visit all of the stores. Instead, decisions are based on store profiles, where each location has a different model of capacity and demand. This practice has the partial effect of homogenising the selection across the chain as store managers are left to service the consumer. Even divisional head offices are left with only buying functions and human resources duties, as other back of the house functions are centralised by Federated itself. Again restructuring was a contested terrain, resisted within the stores, as 'in a big corporation you are always protecting your responsibilities and not giving them up and that is always a fight and a struggle within the industry' (Interview 10).

There remains, despite the centralising ethic of the 1990s, a need for localised attention, as some of the idiosycracies of the market are lost through at-a-distance conception. Firstly, as department stores carry high cost, luxury goods, more sensitive to spatial variations in demand, there is a greater need for local presence and tacit knowledge on the part of buyers than in the retailing of more standard and staple items. Department store buyers do spend a certain amount of time visiting stores to view how products are selling and how consumers receive merchandising. This may not be for all of the stores for which s/he is responsible, but viewing a cross-section remains critical. Secondly, it is still widely viewed that isolated codified knowledge of sales data and forecasting remains insufficient on which to make the merchandising decision exclusively. The fact that the buying function has been retained at the divisional level and not centrally pooled is indicative of the view that 'the customer changes and the weather changes are hard to simply put on a computer screen. We are in the fashion business. If we were just in the blender and toaster and business that would be easy.... so we have to understand the consumers changing lifestyles and be on top of that. It is different in California than it is in Brooklyn and I think that's important' (Terry Lundgren, President, Federated Department Stores, Interview 23). Some executives concede that the codified knowledge created "at a distance" cannot replace the tacit knowledge established in local market settings. Peter Sachse, Director of Stores for Macy's East admits:

What sells in Atlanta does not necessarily sell on Long Island. We run stores in Atlanta and Long Island. In order to be good at our jobs we need to know the nuances of those two marketplaces....But we are not as good as it, quite frankly, as the people were who were in Atlanta when they woke up every morning, living in the city where they were selling the product... We have a sister division in Florida called Burdines, they wake up everyday and it is 80 degrees, when they are waking up and it is 80 , our buyers are waking up and it is 20. It is hard to think about short sleeve shirts that we need to buy and retail in south Florida when it is 20 degrees. It is easy to think about them when it is 80 , so again we get a little bit better at this every day. But do I think our buyers know the Florida market as well as the Florida buyers? No I don't believe they do. I think that Burdines buyers know their market better than our buyers. We have to get better at it....So there is a fine line between centralisation and economies of scale and expertise in a particular marketplace. Our folks I think do a terrific job. 87 stores, 87 different profiles. Every store has got a different profile; although we try to bunch them they still have different ones (Interview 19, my emphasis). 
To overcome some of the difficulties that differing store profiles create there is a planning function within the divisions that allows individual stores to edit and tailor their mixes to their specific markets. This allows, what Swinyard (1997) regards a 'micromarketing'. There are consequently clear costs and benefits from operating at the centralised and decentralised spatial scales, as a trade off against these contravening tendencies is the result (see table 7).

\section{THE DECENTRALISATION - CENTRALISATION DEBATE IN CONTEXT}

The developments in the geographies of department store merchandising and operations feed into many of the recent debates on the geographies of knowledge in economic geography. This centres on the battle between the role of tacit knowledge at the local level and explicit knowledge at central nodal points (see French, 2000, p116). As has been acknowledged, the literature has made much of tacit knowledge at the level of the region, as research on industrial clusters and learning regions in terms of relational geographical proximity has increased. Such work, although informative and interesting, tends to overshadow the value in codified knowledge and explicit knowledge feeding from these decentralised spaces. Indeed, this paper has provided a commentary on the movement away from the wholly decentralised operations, as control has centralised and tacit knowledge is gradually becoming less valued. As such, I agree with the conclusions of Amin and Cohendet (1999) who set about questioning 'the separability of the two forms of knowledge and by suggesting that business networks largely dependent on local tacit knowledge and incremental learning may prove to be inadaptable in the face of radical shifts in markets and technologies' (p88).

The current challenge for department store retailers, as Dawson (2000) has noted more generally, is 'to enable the store management to maintain links to the buyers and strategists in head office as well as to the customers but within the structure of a very large firm' (p125). As the technologies available to retailers have developed, it has been increasingly possible to change tacit knowledge, on the trends and demands of the local market, to produce an abstraction of codified knowledge at a central nodal point. This transformation has had the effect of conflating distance, as capital replaces labour at the local level. These expert systems have the potential to determine the replenishment from basic items in department stores centrally, without the express attention of the buyer.

\section{A Blend of Spatial Scales}

Knowledge acquired exclusively at any one spatial level is likely to be inaccurate. As Schoenberger (1999) has suggested more generally, 'situated knowledge is mistaken for universal knowledge with all the errors that this can entail' (Schoenberger, 1999, p208; cf. Haraway, 1991). Even codified knowledge received "at a distance" at buying offices is acknowledged to be partial, as a company executive from Saks Fifth Avenue admitted:

We somehow need to come up with a better system than we are doing it because having the buyers, I do a lot of store training, so I travel across the country and listen to the stores problems, when you have someone in New York making a decision for someone in California, what you perceive or what you think you are reading on the computer is not really what's going on. If people are trying to tell you that you are selling merchandise and you are looking at numbers and saying 'you only sold 8', how can you say you are really selling it? Answer: 'But you have only given me 3 (Interview 2).

A mix of scales is necessary. Yeung et al. (2001) commented more generally: firstly some degree of 'localised management is required to fully understand the nature of the ever changing conditions of the region, and secondly "managing from a distance"...is no longer an acceptable tool for strategic management in a world of keen competition and high demand for local responsiveness' (p3). As a result, buyers are still located at the divisional level, as it is felt that the combination of tacit/local knowledge (i.e. being near their markets) is important, but at the same time, benefiting from the matrix of selections developed centrally by the headquarters merchandising group. This centralisation represents a movement away from the belief, especially inherent with early 1980s department store organisational structure, that there is a need to spend extensive amount of time on the shop floor to pick up on the 'mood' of what is demanded. Instead, codified knowledge of sales reports and mathematical models of estimates, supplement the decision making process. In addition, many of the operations that were decentralised are now operated at central locations again facilitated by technological innovations and the economies of scale available to larger retailers due to the acquisition based portfolio restructuring (Wood, 2000). This blend of tacit and specific knowledge thus 'fuses data and instinct with corporate models and analysis to create a high-tech forecasting system' (Fisher et al., 2000, p 116), providing evidence that a dual structure of organisation is emerging, mediating between these two spatial scales of organisation, as displayed in figure 4.

Thus a dual structure seems to be emerging, which is composed of a decentralised network of reflexive and interactive centres to advance core competencies and learning and overlaid upon a more traditional hierarchical structure for the regulation of noncore activities. In such a context, the key challenge facing firms and business 
systems concerns less the transition from one structure to the other than the integration of the two structures into a coherent whole (Amin and Cohendet, 1999, p88, my emphasis).

The construction of such a new organisational configuration has been actively contested over time. As Schoenberger $(1994 ; 1997)$ has suggested, individuals have different value asymmetries to that of the firm and are thus keen to protect their own established roles. Consequently, divisions were immediately resistant to loosing functions to the centralised back-of-the-house operational units. In addition, buyers remain resistant to basic merchandise being replenished automatically through the Quick Response system. It is clear there are many cultures and subcultures within an organisation that are seeking legitimacy in the face of the dominant central vision:

The firm's dominant culture, created by and expressed through the activities and understandings of top management at headquarters, necessarily contains multiple subcultures. Some of these may revolve around functions that cut across places...but some will have real geographical locations - they will have grown up in specific...places. It follows from this that the interesting locus of study and of transformative processes is not only where "the firm" (conceived as unitary agent) meets the world (competitors, markets, suppliers), but also internally as competing subcultures strive for validation and expression (Schoenberger, 1999, p211)

The transition from tacit to codified knowledge in controlling nodes is not unique to the U.S. department store industry and compares with the revolutions evident in recent organisational restructuring in the operations of U.K. retail banks (see Leyshon and Thrift, 1995). Here, there has also been a distanciation away from decentralised authority with the utilisation of codified knowledge "at a distance", to make decisions on loans and insurance to distinguish between good and bad credit risks. Previously, physical proximity of branches allowed banks to obtain rich, customised, 'softer' information (Alexander and Pollard, 2000; cf. Thrift, 1997). This codified knowledge of credit scoring has replaced the tacit knowledge of trust and reliability (see Leyshon and Thrift, 1999; Leyshon et al., 1998). Such literature provides a useful contrast to the recent growth in literature on the specificities of regional learning, tacit knowledge and network linkages. As such ' $(\mathrm{t})$ here is a danger... that the discovery of local relational learning environments ends up proclaiming the superiority of tacit knowledge, based on face-to-face contact, over codified knowledge, based on scientific discovery, technological enhancement, and distantiated conditions' (Amin and Cohendet, 1999, p90). Conversely, the retailer must not remove the sensitivity to the decentralised divisional and branched level, as these knowledges remain important contributions to successful retail operations. As Schoenberger (1999) comments in a more general context, firms are 'figuring out ways to support this emerging corporate region so that at least it is less likely to be snuffed out by a recalcitrant headquarters' (p222). This paper has shown that only when a mixture of the two spatial scales is brought together can successful execution be achieved and begin to overcome the traditional conflict between integration and independence of department stores (see table 7). The relationship between centralisation and decentralisation remains in a state of flux within, and between, organisations, as the capability of technological systems to conflate distance changes. It is to these spatial aspects of distribution that retail geographers should start to pay greater attention.

\section{ACKNOWLEDGEMENTS}

This project is part of the larger project; 'The Restructuring of the U.S. Department Store Industry', supported by the John Lewis Scholarship at the Department of Geography, University of Southampton. The author is grateful to all those who participated in the research. I thank Neil Wrigley, Sallie Marston and Howard Biederman, as well as an anonymous referee for insightful discussions on many of the subjects surrounding this work. All omissions and errors remain my own.

\section{REFERENCES}

Abelson, E. S. (1989) When Ladies go a-thieving: Middle-Class Shoplifters in a Victorian Department Store, Oxford University Press, New York.

Abernathy, F., Dunlop, J., Hammond, J., Weil, D. (1999) A Stitch in Time. Lean Retailing and the Transformation of Manufacturing - Lessons form the Apparel and Textile Industries, Oxford University Press, Oxford.

Alexander, A. and Pollard, J. (2000) 'Banks, grocers and the changing retailing of financial services', Journal of Retailing and Consumer Services, 7, 137-147. 
American Apparel Producers' Network (1999) Fulfilment: How 'Quick Response' Works in the American Apparel Industry. Posted at (http://usawear.org/qr.htm), accessed on 28 February 2000.

Amin, A. and Thrift, N. (eds.) (1994) Globalization, institutions, and regional development in Europe, Oxford University Press, Oxford.

Amin, A. and Cohendet, P. (1999) 'Learning and adaptation in decentralised business networks', Environment and Planning B: Society and Space, 17, 87-104.

Aufreiter, N., Kurch, N. and Smith Shi, C. (1993) 'The Engine of Success in Retailing', The McKinsey Quarterly, No. 3, 101-116.

Bailey, T. and Bernhardt, A. (1996) The Reorganization of the Workplace in Service Industries: Effects on job quality and organizational performance, NCW Working Paper Series No. 7, Institute of Industrial Relations, University of California, Berkeley.

Blomley, N. (1996) 'I'd like to dress her all over': Masculinity Power and Retail Space'. In N. Wrigley and M. S. Lowe (eds.), Retailing Consumption and Capital: Towards the New Retail Geography, Longman, London.

Bluestone, B., P. Hanna, S. Kuhn, L. Moore (1981) The Retail Revolution. Market Transformation, Investment and Labor in the Modern Department Store, Auburn House, Boston.

Biederman, H. W. (1991) Strategic Restructuring in the US Department Store Industry. Unpublished Working Paper No. 9101, Institute for Retail Studies, University of Stirling.

Bowlby, S., Foord, J. and Tillsley, C. (1992) 'Changing consumption patterns: impacts on retailers and their suppliers', International Review of Retail, Distribution and Consumer Research, 2, 133-150.

Burt, S. (2000) 'The strategic role of retail brands in British grocery retailing', European Journal of Marketing, 34 (8), 875-891.

Burt, S. and Sparks, L. (1993) 'Structural change in grocery retailing in Great Britain: a discount re-orientation?', International Review of Retail Distribution and Consumer Research, 4, 195-217.

Chandler, A. D. Jr. (1990) Scale and Scope: the dynamics of industrial capitalism, Harvard University Press, Cambridge, MA.

Christopherson, S. (1996) 'The production of consumption: retail restructuring and labour demand in the USA'. In Wrigley, N and Lowe, M. S. (eds.), Retailing Consumption and Capital: Towards the New Retail Geography, Longman, London, pp159-177.

Clark, F. E., Onthank, H., Dodd, A. E., Nystrom, P. H., Griffen, C. E., Lyon, L. S., McGarry, E. D. (1926) 'Reducing the costs of marketing'. Papers and Proceedings of the Thirty-Eighth Annual Meeting of the American Economic Association, The American Economic Review, 16 (1), 250-265.

Crewe, L. (2000) 'Geographies of retailing and consumption', Progress in Human Geography, 24 (2), 275-290.

Crewe, L. and Davenport, E. (1992) 'The puppet show: changing buyer-supplier relationships within clothing retailing, Transactions of the Institute of British Geographers N. S., 17, 183-197.

Crossick, G. and Jaumain, S. (eds.) (1999) Cathedrals of Consumption: The European Department Store, 1850 1939, Ashgate Publishing, Aldershot

Dawson, J. (2000) 'Retailing at century end: some challenges for management and research', International Review of Retail, Distribution and Consumer Research, 10 (2), 119-148.

Deloitte and Touche (1998) United States Department Store Industry, Unpublished Report, Deloitte and Touche Tohmatsu, New York.

Doel, C. (1999) 'Towards a supply-chain community? Insights from governance processes in the food industry', Environment and Planning A, 69-85. 
Domosh, M. (1996a) Invented Cities, Yale University Press, New Haven.

Domosh, M. (1996b) 'The feminized retail landscape: gender ideology and consumer culture in 19th century New York City. In N. Wrigley and M. S. Lowe, (eds.), Retailing Consumption and Capital: Towards the New Retail Geography, Longman, London.

Dowling, R. (1993) 'Femininity, place and commodities: a retail case study', Antipode, 25, 295-319.

Ernst and Young LLP (1998) Retail IT - Ernst \& Young's $17^{\text {th }}$ Annual Survey of Retail Information Technology, Ernst and Young LLP.

Evans, P. B. and Wurster, T. S. (1997) 'Strategy and the new economics of information', Harvard Business Review, 75 (5). Reprinted in Tapscott, D. (ed.) (1999) Creating Value in the Network Economy, Harvard Business Review Press, Boston. MA, pp13-34.

Fernie, J. (1994) 'Quick response: an international perspective', International Journal of Physical Distribution and Logistics Management, 24 (6), 38-46.

Fernie, J. and Fernie, S. (1997) 'The development of a US retail format in Europe: the case of factory outlet centres', International Journal of Retail and Distribution Management, 25, 342-350.

Fiorito, S. S., May, E. G. and Straughn, K. (1995) 'Quick response: components and implementation’, International Journal of Retail and Distribution Management, 23 (5), 12-21.

Fisher, M., Raman, A. and McClelland, A. (2000) 'Rocket science retailing is almost here. Are you ready?', Harvard Business Review, 78 (4), 115-127.

Forsyth, J. N. (1993) 'Department store restructures for the 90s', Chain Store Age Executive, August 1 1993, p29A.

Freathy, P. and Sparks, L. (1996) 'Understanding Retail Employment Relations'. In Wrigley, N and Lowe, M. S. (eds.), Retailing Consumption and Capital: Towards the New Retail Geography, Longman, London, pp178-195.

French, S. (2000) 'Re-scaling the economic geography of knowledge and information: constructing life assurance markets', Geoforum, 31, 101-119.

George, M., Freeling, A. and Court, D. (1994) 'Reinventing the marketing organisation', The McKinsey Quarterly, No. 4, 43-52.

Giddens, A. (1991) The Consequences of Modernity, Polity Press, London.

Gold, P., Woodliffe, L. (2000) 'Department stores in Spain: why El Corte Ingle's succeeded where Galerías Preciados failed', International Journal of Retail \& Distribution Management ; 28 (8) 2000, 333 - 340.

Goss, J. (1993) 'The magic of the mall: an analysis of form, function and meaning in the contemporary retail built environment', Annals of the Association of American Geographers, 83, 18-47.

Goss, J. (1999) 'Once-upon-a-time in the commodity world: An unofficial guide to mall of America', Annals of the Association of American Geographers, 89 (1), 45-75.

Green, M. B. (1990) Mergers and Acquisitions. Geographical and Spatial Perspectives, Routledge, New York.

Gregson, N., Longstaff, B. and Crewe, L. (1997) 'Excluded spaces of regulation: car boot sales as an enterprise culture out of control?', Environment and Planning A, 29 (10), 1717-1737.

Guy, C. (1998) 'Alternative-use valuation, open A1 planning consent, and the development of retail parks', Environment and Planning A, 1998, 30, 37 - 47.

Hallsworth, A. G. (1991) 'The Campeau Takeovers: The Arbitrage Economy In Action', Environment and Planning A, 23, 1217-1223. 
Hallsworth, A. G. and Taylor, M. (1996) “ "Buying power" - interpreting retail change in a circuits of power framework', Environment and Planning A, 28, 2125-2137.

Hansen, T. and Skytte, H. (1998) 'Retailer buying behaviour: a review', The International Review of Retail, Distribution and Consumer Research, 8 (3), 277-301.

Haraway, D. (1991) Simians, Cyborgs, and Women: The Reinvention of Nature, Routledge, New York.

Harvey, D. (1982) The Limits to Capital, Blackwell, Oxford.

Hayek, F. A. (1945) 'The use of scientific knowledge in society', American Economic Review, 35 (4).

Henry, N. and Pinch, S. (2000) 'Spatialising knowledge: placing the knowledge community of Motor Sport Valley', Geoforum, 31 (2), 191-208.

Hippel, E. (1999) “'Sticky information” and the locus of problem solving: implications for innovation'. In A. Chandler Jr., P. Hagstrom and O. Solvell (eds.) (1999) The Dynamic Firm. The Role of Technology, Strategy, Organization, and Regions, Oxford University Press, Oxford, pp 60-77.

Hopkins, J. S. (1990) 'West Edmonton Mall: landscape of myths and elsewhereness', Canadian Geographer, 34, 217.

Hughes, A. (1999) 'Constructing competitive spaces: on the corporate practice of British retailer-supplier relationships'. Environment and Planning A, 31, 819-839.

Hughes, A. (2000) 'Retailers, knowledges and changing commodity networks: the case of the cut flower trade', Geoforum, 31 (2), 175-190.

Jackson, P. (1993) 'Towards a Cultural Politics of Consumption'. In J. Bird, B. Curtis, T. Putman, G. Robertson, L. Tickner (eds.), Mapping the futures: Local cultures, global change, Routledge, London.

Jackson, P. and Holbrook, B. (1995) 'Multiple Meanings: Consumption and the Cultural Politics of Identity', Environment and Planning A, 27, 1913-1930.

Jackson, P., Lowe, M., Miller, D. and Mort, F. (eds.) (2000) Commercial Cultures, Berg, London.

Jackson, P. and Taylor, J. (1996) 'Geography and the cultural politics of advertising', Progress in Human Geography, 20, 356-371.

Jensen, M. and Meckling, W. (1992) 'Specific and general knowledge, and organizational structure'. In L. Werin and H. Wijkander (eds.), Contract Economics, Blackwell, Oxford, pp251-274.

Keeble, D., Lawson, C., Moore, B. and Wilkinson, F. (1999) 'Collective learning processes, networking and "institutional thickness" in the Cambridge region', Regional Studies, 33 (4), 319-332.

Krugman, P. (1998) 'What's new about the new economic geography', Oxford Economic Policy Review, 14 (2), 7 17.

Kumar, N. (1996) 'The power of trust in manufacturer-retailer relationships', Harvard Business Review, 74 (6), 92106.

Laulajainen, R. (1987) Spatial Strategies in Retailing, D. Reidel Publishing, Dordrecht.

Laulajainen, R. (1988) ‘The spatial dimension of an acquisition', Economic Geography, 64, 171-187.

Laulajainen, R. (1990) 'Defense by expansion', Professional Geographer, 42 (3), 277-288.

Leslie, D. and Reimer, S. (1999) 'Spatializing commodity chains', Progress in Human Geography, 23 (3), 401-420.

Leyshon, A. and Thrift, N. (1995) 'Geographies of financial exclusion: financial abandonment in Britain and the United States', Transactions of the Institute of British Geographers, 20, 312-41. 
Leyshon, A. and Thrift, N. (1999) 'Lists come alive: electronic systems of knowledge and the rise of credit scoring in retail banking', Economy and Society, 28 (3), 434-466.

Leyshon, A., Thrift, N. and Pratt, J. (1998) 'Reading financial services: texts, consumers, and financial literacy', Environment and Planning D: Society and Space, 16 (1), 29-55.

Lovering, J. (1999) 'Theory led policy: the inadequacies of the, new regionalism', International Journal of Urban and Regional Research, 23 (2), 379-395.

Lowe, M. and Wrigley, N. (1996) 'Towards the new retail geography'. In Wrigley, N and Lowe, M. S. (eds.), Retailing Consumption and Capital: Towards the New Retail Geography, Longman, London, pp3-30.

MacPherson, K. L (ed.) (1998) Asian Department Stores, University of Hawaii Press, Hawaii.

McKinnon, A. (1990) 'The advantages and disadvantages of centralised distribution'. In J. Fernie (ed.) (1990) Retail Distribution Management - A Strategic Guide to Developments and Trends, Kogan Page, London, pp75-89.

Malone, T. W. and Laubacher, R. J. (1998) 'The dawn of the E-lance economy', Harvard Business Review 76 (5). Reprinted in Tapscott, D. (ed.) (1999) Creating Value in the Network Economy, Harvard Business Review Press, Boston. MA, pp55-68.

Maltz, E. and Srivastava, R. (1997) 'Managing retailer-supplier partnerships with EDI: evaluation and implementation, Long Range Planning, 30, 862-876.

Markusen, A. (1996) 'Sticky places in slippery space: a typology of industrial districts', Economic Geography, 72, 293-313.

Marsden, T. and Wrigley, N. (1995) 'Regulation, Retailing and Consumption', Environment and Planning A, 27, 1899-1912.

Marsden, T, Flynn A, Harrison M (2000) Consuming Interests. The Social Provision of Foods (UCL Press, London).

Martin, R. (1994) 'Statelesss monies, global financial integration and national economic autonomy: The end of geography?’ In S. Corbridge, R. Martin and N. Thrift (eds.) Money, Space and Power, Basil Blackwell, Oxford.

Martin, R. (1999) 'The 'new economic geography': challenge or irrelevance?', Transactions of the Institute of British Geographers N.S., 24, 387-391.

Miller, D. (1998) A Theory of Shopping, Cornell University Press, New York.

Miller, D. (2000), The Dialectics of Shopping, University of Chicago Press, Chicago.

Miller, D., Jackson, P., Thrift, N., Holbrook, B. and Rowlands, M. (1998) Shopping, Place and Identity, Routledge, London.

Moore, J. F. (1993) 'Predators and prey: a new ecology of competition', Harvard Business Review, May-June 1993. Reprinted in D. Tapscott (ed.) Creating Value in the Network Economy, Harvard Business Review Press, Cambridge MA, pp121-143.

Morganosky, M. A. (1997) 'Retail market structure change: implications for retailers and consumers', International Journal of Retail and Distribution Management, 25 (8), 269-274.

Mort, F. (1996) Cultures of Consumption - Masculinities and Social Space in Late Twentieth Century Britain, Routledge, London.

Nava, M. (1996) 'Modernity's disavowel. Women, the city and the department store'. In M. Nava and A O'Shea (eds.), Modern Times: Reflections on a century of English modernity, Routledge, London, pp38-76.

O’Brien, R. (1992) Global Financial Integration. The End of Geography, Pinter, London. 
Phillips, L. A., Sternquist, B. and Mui, S. (1992) 'Hong Kong department stores: retailing in the 1990s', International Journal of Retail and Distribution Management, 20 (1), 16-24.

Porteous, D. (1999) 'The development of financial centres: location, information externalities and path dependence'. In R. Martin (ed.) (1999) Money and the Space Economy, Wiley, London, pp95-114.

Porter, J. (1999) The Future of the Department Store Industry: Instore and Mail Order Strategies, Financial Times Retail and Consumer, London.

Reekie, G. (1993) Temptations. Sex, Selling and the Department Store, Allen and Unwin, Sydney.

Rothchild J, 1991 Going for Broke: How Robert Campeau Bankrupted the Retail Industry, Jolted the Junk Bond Market and Bought the Booming '80s to a Crashing Halt, Beard Books, Washington DC.

Schoenberger, E. (1994) 'Corporate strategy and corporate strategists: power, identity and knowledge within the firm', Environment and Planning A, 26, 435-451.

Schoenberger, E. (1997) The Cultural Crisis of the Firm, Blackwell, Oxford.

Schoenberger, E. (1999) 'The firm in the region and the region in the firm'. In T. J. Barnes and M. S. Gertler (eds.), The New Industrial Geography: Regions, Regulation and Institutions, Routledge, London, pp205-224.

Shackleton, R. (1998) 'Exploring corporate culture and strategy: Sainsbury at home and abroad during the early to mid 1990s', Environment and Planning A, 30, 921-940.

Shields, R. (ed.) (1992) Lifestyle Shopping, Routledge, London.

Smith, M. D. (1998) 'The empire filters back: consumption, production, and the politics of Starbucks coffee', Urban Geography, 17 (6), 502-524.

Smith, S. (1988) 'How much change in store? The impact of new technologies and labour processes on manager and staffs in retail distribution'. In D. Knights and H. Willmott (eds.) (1988), New Technology and the Labour Process, Macmillan, London, pp143-162.

Smith, D. and Sparks, L. (1993) 'The transformation of physical distribution in retailing', International Review of Retail, Distribution and Consumer Research, 3, 35-64.

Sparks, L. (1994) 'Delivering quality: the role of logistics in the post-war transformation of British food retailing. In G. Jones and N. J. Morgan (eds.) Adding Value: Brands and Marketing in Food and Drink, Routledge, London, pp310-335.

Sparks, L. (1995) 'Restructuring Scottish grocery retailing: the irse and demise of Shoprite and Wm Low', International Journal of Retail and Distribution Management, 23(10), 28-36.

Sternquist, B. and Byoungho Jin (1998) 'What sets the United States retail industry apart from other countries?' Korean Distribution Journal (In Korean) December

Storper, M. (1997) The Regional World: Territorial Development in a Global Economy, Guilford Press, New York.

Storper, M. and Salais, R. (1997) Worlds of Production: The Action Frameworks of the Economy, Harvard University Press, Cambridge, MA.

Swinyard, W. R. (1997) 'Retailing trends in the USA: competition, technology and the economy', International Journal of Retail and Distribution Management, 25 (8), 244-255.

Thrift, N. (1985) 'Flies and germs: a geography of knowledge'. In D. Gregory and J. Urry (eds.) Social Relations and Spatial Structures, Macmillan, London, pp366-403.

Thrift, N. (1994) 'On the social and cultural determinants of international financial centres: The case of the City of London'. In S. Corbridge, R. Martin and N. Thrift (eds.) Money, Space and Power, Basil Blackwell, Oxford. 
Thrift, N. (1997) 'The rise of soft capitalism', Cultural Values, 1, 57.

Trachtenberg, J. A. (1996) The Rain on Macy's Parade, Times Books, New York.

Vance, S. S. and Scott, R. V. (1994) Wal-Mart : A History of Sam Walton's Retail Phenomenon, Twayne's Evolution of Modern Business Series, No 11, Twayne Publishers.

Wall, M., Sommers, M. and Wilcock, A. (1994) 'The retail buying of fashion goods: underlying themes of the sourcing process', International Review of Retail, Distribution and Consumer Research, 2, 133-150.

Walker, R. (1989) 'A requiem for corporate geography: new directions in industrial organisation, the production of place and uneven development', Geografiska Annaler, 71 B: 43-68.

Wood, S. M. (2000) Regulatory Constrained Portfolio Restructuring: The Case of the U.S. Department Store, Unpublished Manuscript. Copy available from author; Dept. of Geography, University of Southampton, SO17 1BJ.

Wrigley, N. (1991) 'Is the golden age of British grocery retailing at a watershed?', Environment and Planning A, 23, $1537-1544$.

Wrigley, N. (1992) 'Antitrust legislation and the restructuring of grocery retailing in Britain and the USA', Environment and Planning A, 24, 727-41.

Wrigley, N. (1993) 'Retail concentration and the internationalization of British grocery retailing'. In R. Bromley and C. Thomas (eds.), Retail Change, UCL Press, London, pp41-68.

Wrigley, N. (1998a) 'European retail giants and the post-LBO reconfiguration of U.S. food retailing', International Review of Retail, Distribution and Consumer Research, 8, 127-146.

Wrigley, N. (1998b) 'Understanding store development programmes in post-property-crisis UK food retailing', Environment and Planning A, 30, 15-35.

Wrigley, N. (1998c) 'How British food retailers have shaped food choice'. In A. Murcott (ed.), The Nations Diet The Social Science of Food Choice, Longman, London, pp112-128.

Wrigley N. (1999a) 'Leveraged restructuring and the economic landscape: the LBO wave In U.S. food retailing'. In R. L. Martin (ed) Money and the Space Economy (John Wiley, Chichester) pp185-204

Wrigley, N. (1999b) 'Market rules and spatial outcomes: Insights from the corporate restructuring of U.S. food retailing', Geographical Analysis, 31 (3), 288-309.

Wrigley, N. (2000a) 'Strategic market behaviour in the internationalization of food retailing: interpreting the third wave of Sainbury's US diversification', European Journal of Marketing, 34 (8), 891-918.

Wrigley, N. (2000b) 'The globalization of retail capital: themes for economic geography'. In Clark, G. L., M. S. Gertler, M. Feldman (eds.), Handbook of Economic Geography, Oxford University Press, Oxford.

Wrigley, N. (2000c) 'Transforming the corporate landscape of U.S. food retail: market power, financial reengineering, and regulation', Tijdschrift voor Econmische en Sociale Geographie, This Volume

Wrigley, N. and Lowe, M. S. (eds.) (1996), Retailing Consumption and Capital: Towards the New Retail Geography, Longman, London.

Wrigley, N. and Lowe, M. S. (2001) Reading Retail: A Geographical Perspective on Retailing and Consumption Spaces, London: Arnold.

Yeung, H. (1994) 'Critical reviews of geographical perspectives on business organizations and the organization of production: towards a network approach', Progress in Human Geography, 18 (4), 460-490. 
Yeung, H. (2000a), Reconceptualising the "Firm" in New Economic Geographies: An Organisational Perspective, Paper Presented at the Workshop on "'The Firm' in Economic Geography", University of Portsmouth, U.K., 9-11 March 2000.

Yeung, H. (2000b), 'Organising "the firm” in industrial geography I: networks, institutions and regional development', Progress in Human Geography, 24(2), pp.301-15.

Yeung, H., Poon, J., Perry, M. (2001) 'Towards a regional strategy: the role of regional headquarters of foreign firms in Singapore, Mimeo. Forthcoming in Urban Studies, 38 (1).

Zukin, S. and Dimaggio, P. (1990) 'Introduction'. In S. Zukin and P. Dimaggio (eds.), Structures of Capital: The Social Organisation of the Economy, Cambridge University Press, pp1-36. 
Table 1 The Conventional U.S. Department Store Industry Sales and Market Shares For Fiscal Years 1997 and 1998

\begin{tabular}{|c|c|c|c|c|c|c|c|}
\hline \multicolumn{4}{|c|}{ Fiscal 1997 } & \multicolumn{5}{c|}{ Fiscal 1998 } \\
\hline 1997 & Firm & $\begin{array}{c}1997 \\
\text { Sales } \\
\text { Rank }\end{array}$ & $\begin{array}{c}1997 \\
\text { Market } \\
\text { Share }(\%)\end{array}$ & $\begin{array}{c}1998 \\
\text { Rank }\end{array}$ & Firm & $\begin{array}{c}1998 \\
\text { Sales } \\
(\$ \text { mill })\end{array}$ & $\begin{array}{c}1998 \\
\text { Market } \\
\text { Share }(\%)\end{array}$ \\
\hline 1 & Federated & 15,668 & 26.9 & 1 & Federated & 15,833 & 26.2 \\
\hline 2 & May & 12,352 & 21.2 & 2 & May & 13,072 & 21.7 \\
\hline 3 & Dillard & 6,632 & 11.4 & 3 & Dillard (b) & 9,185 & 15.2 \\
\hline 4 & Nordstrom & 4,852 & 8.3 & 4 & Saks Inc.(c) & 6,220 & 10.3 \\
\hline 5 & Proffitt's & 3,545 & 6.1 & 5 & Nordstrom & 5,028 & 8.3 \\
\hline 6 & Dayton Hudson (a) & 3,162 & 5.4 & 6 & Dayton Hudson (a) & 3,285 & 5.4 \\
\hline 7 & Mercantile & 3,055 & 5.2 & 7 & Belk & 2,091 & 3.5 \\
\hline 8 & Belk & 2,042 & 3.5 & 8 & Neiman Marcus (a) & 2,090 & 3.5 \\
\hline 9 & Neiman Marcus (a) & 1,951 & 3.3 & 9 & Boscov's (d) & 846 & 1.4 \\
\hline 10 & Saks Holdings & 1,835 & 3.1 & 10 & Bon-Ton & 675 & 1.1 \\
\hline
\end{tabular}

Total U.S. conventional department store sales (e):

\section{7: $\$ 58,335$ million 1998: $\$ 60,469$ million}

N.B. Although the subject of considerable corporate restructuring, the U.S. conventional department store industry only represents approximately 8.2\% of GAF (General merchandise, apparel and furniture) sales in fiscal 1998.

(a) Sales include only department store business

(b) Dillard acquired Mercantile stores August 13 1998. Mercantile sales (pre-merger) until August 1 for fiscal 1998 (\$1,388,027) are added to Dillard figure of $\$ 7.797 \mathrm{bn}$.

(c) Proffitt's, Inc. and Saks Holdings merged September 1998 to form Saks Inc.

(d) Includes sales from Boscov's TravelCenter, a travel agency

(e) This is a JP Morgan estimate and does not equate to the US Census Bureau's definition of a conventional department store. The U.S. Census Bureau regard the high end department stores (including Saks Fifth Avenue, Bloomingdale's, Nordstrom and Lord and Taylor) to be outside the conventional department store industry because they do not sell enough furniture, appliances and household items. Despite this, these stores are still typically considered to be part of the sector by the public, and indeed by many within the industry itself (see Deloitte and Touche, 1998, p 11).

Source: data from U.S. Commerce Bureau; J. P. Morgan Securities; Company Reports and 10K Reports submitted to the U.S. Securities and Exchange Commission. 
Table 2 Department Store Acquisitions of the 1990s.

\begin{tabular}{|c|c|c|c|c|}
\hline Date & Acquirer & $\begin{array}{c}\text { Acquired (Geographical } \\
\text { Area) }\end{array}$ & $\begin{array}{c}\text { Cost } \\
\text { (If known) }\end{array}$ & $\begin{array}{l}\text { No of Stores } \\
\text { (If known) }\end{array}$ \\
\hline 1990 & May & $\begin{array}{c}\text { Thalhimers, (Richmond, } \\
\text { Va.), Sibley's, (Rochester, } \\
\text { N.Y.) }\end{array}$ & $\mathrm{N} / \mathrm{D}$ & 26 \\
\hline 1990 & Dayton Hudson & Marshall Field (Midwest) & $\$ 1.4$ billion & $\mathrm{N} / \mathrm{D}$ \\
\hline $\begin{array}{c}\text { Oct 1992-July } \\
1993\end{array}$ & Proffitt's & Hess (Southeast) & $\$ 24$ million & 18 \\
\hline March 1994 & Proffitt's & McRae's (Southeast) & f212 million & 28 \\
\hline 1994 & Bon-Ton & Hess & $\mathrm{N} / \mathrm{D}$ & 20 \\
\hline 1994 & May & $\begin{array}{c}10 \text { stores from Hess } \\
\text { (Northeast) }\end{array}$ & $\mathrm{N} / \mathrm{D}$ & 10 \\
\hline May 1994 & Federated & Joseph Horne Co. & $\$ 116$ million & 10 \\
\hline Dec 1994 & Federated & R. H. Macy & $\$ 4.1$ billion & 123 \\
\hline April 1994 & Proffitt's & Parks-Belk & Less than $\$ 20$ million & 3 \\
\hline July 1995 & $\begin{array}{l}\text { May and J. C. } \\
\text { Penney }\end{array}$ & $\begin{array}{c}\text { Woodward and Woodward } \\
\text { \& Lothrop stores }\end{array}$ & Total Cost $\$ 460$ million & 21 \\
\hline Aug 1995 & Federated & Broadway & $\$ 1.6$ billion & 82 \\
\hline April 1996 & May & $\begin{array}{l}13 \text { Strawbridge \& Clothier } \\
\text { stores (Philadelphia). }\end{array}$ & $\$ 479.5$ million & 13 \\
\hline Feb 1996 & Proffitt's & Younker's (Midwest) & $\$ 258$ million & 51 \\
\hline October 1996 & Proffitt's & $\begin{array}{c}\text { Parisian (Southwest and } \\
\text { Midwest) }\end{array}$ & $\$ 452$ million & 38 \\
\hline Nov 1996 & Belk & Leggett Stores & $\$ 92$ million & 31 \\
\hline $\begin{array}{c}\text { February } \\
1997 \\
\end{array}$ & Proffitt's & $\begin{array}{l}\text { Herberger's (Midwest and } \\
\text { Great Plains) }\end{array}$ & $\$ 154.9$ million & 40 \\
\hline January 1998 & Proffitt's & $\begin{array}{c}\text { Carson Pirie Scott } \\
\text { (Midwest) }\end{array}$ & $\$ 956$ million & 55 \\
\hline March 1998 & Proffitt's & Broady's (North Carolina) & $\mathrm{N} / \mathrm{D}$ & 6 \\
\hline May 1998 & Dillard & Mercantile & $\$ 2.9$ billion & 103 \\
\hline August 1998 & Gottschalks & $\begin{array}{l}\text { The Harris Company } \\
\text { (California) }\end{array}$ & $\$ 36.1$ million & 9 \\
\hline Sept 1998 & Proffitt's & Saks Holdings (National) & $\$ 2.1$ billion & 96 \\
\hline October 1999 & May & ZMCI (Utah, Idaho) & $\$ 52$ million & 14 \\
\hline
\end{tabular}

Sources: various company reports and 10k's submitted to the Securities and Exchange Commission.

Strategic acquisition-based portfolio restructuring has set the pace for the 1990s department store industry. This has seen large stores acquire, but more interestingly in this decade, regional chains have been consolidated leaving very few available into the $21^{\text {st }}$ century. 
Figure 1 The Trade Off Between Centralisation and Decentralisation

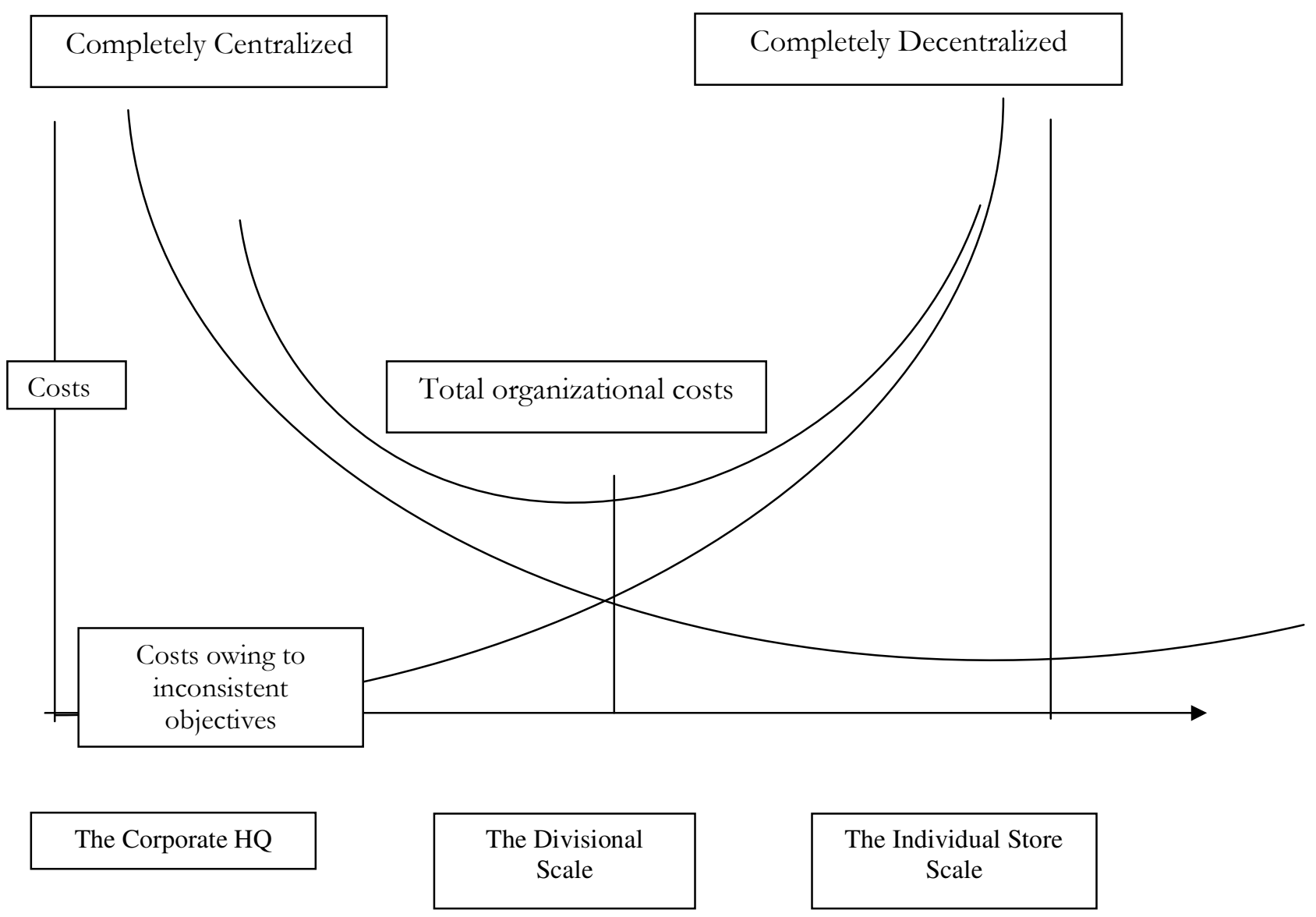

This diagram explains the historical balance required between costly knowledge acquisition at the store level and the need for economical centralised control at the corporate headquarters that has plagued the U.S. department store. It is clear that total costs have traditionally been at a minimum with control decentralised to the divisional level. 
Figure 2 The Speeding Distribution System Under Quick Response

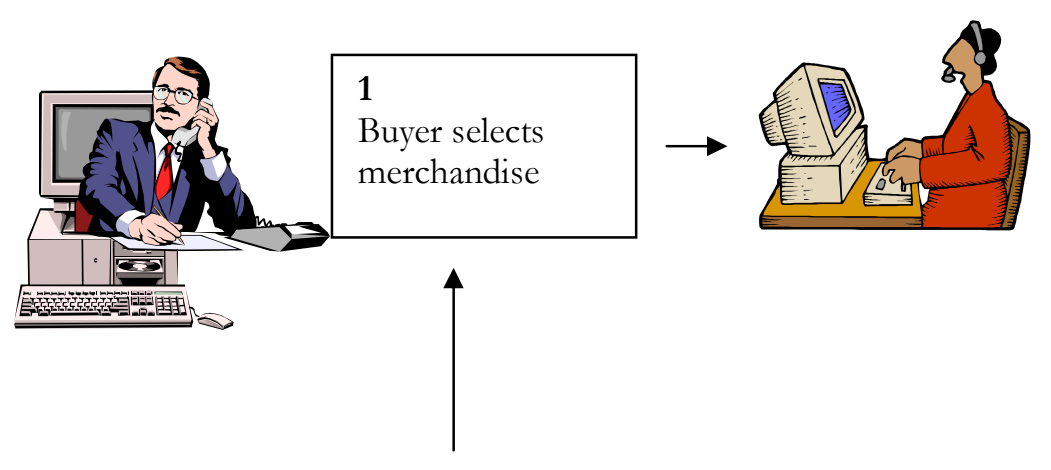

2
Purchase orders are
entered by the buyer or
created by the BARS
system in store and
SKU according to
vendor style \#'s and
descriptions
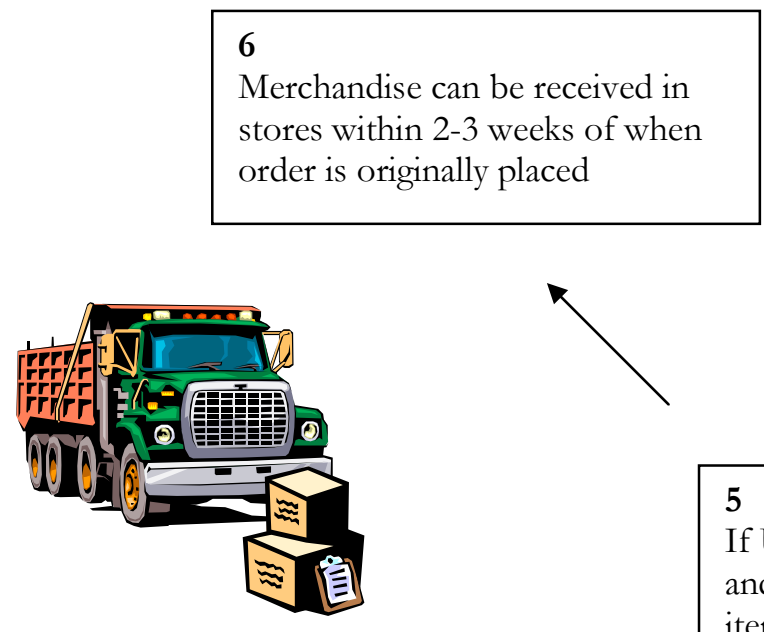

5

If UPC or preticketed

and on approved hangers,

items can be cross-

docked (received and sent

directly to stores)

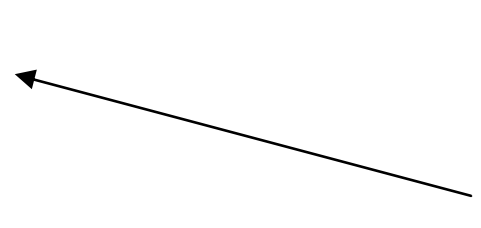

3

Purchase order

communicated to vendor

via EDI. Order is in

vendor's system ready for

allocation

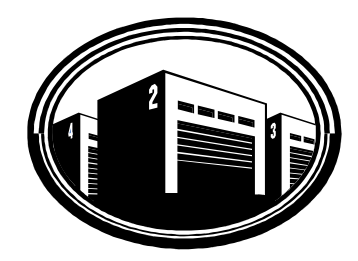

Vendor picks and packs

merchandise (turnaround 3-

10 days) and sends advance

shipment notice (ASN) to

buyer and distribution

centre via Electronic Data

Interchange (EDI) 
Table 3 Merchandise and Knowledge Dependencies in the Supply Chain

\begin{tabular}{l|llll}
\hline $\begin{array}{l}\text { TYPE OF } \\
\text { MERCHANDISE }\end{array}$ & KNOWLEDGE & SCALE & $\begin{array}{l}\text { TARGET } \\
\text { MARKET }\end{array}$ & COMMENTS \\
\hline Basic Merchandise & Codified & National & Universal & $\begin{array}{l}\text { Cheap. Easier } \\
\text { to predict. } \\
\text { Fewer sunk } \\
\text { costs }\end{array}$ \\
& & & & \\
$\begin{array}{l}\text { Fashion } \\
\text { Merchandise }\end{array}$ & $\begin{array}{l}\text { Codified and } \\
\text { Tacit }\end{array}$ & $\begin{array}{l}\text { National } \\
\text { and local }\end{array}$ & $\begin{array}{l}\text { Regional } \\
\text { Markets }\end{array}$ & $\begin{array}{l}\text { Expensive. Vast } \\
\text { geographical } \\
\text { variations. } \\
\text { High sunk costs }\end{array}$ \\
\hline
\end{tabular}

Table 4 Federated's Department Store Chains 1999.

\begin{tabular}{c|cc}
\hline Chain & Number of Stores & 1998 Annual Sales \\
\hline Macy's East & 87 & $\$ 4.587$ billion \\
Macy's West & 100 & $\$ 3.866$ billion \\
Rich's/Lazurus/Goldsmith's & 76 & $\$ 2.186$ billion \\
Bloomingdale's & 24 & $\$ 1.922$ billion \\
Burdines & 49 & $\$ 1.400$ billion \\
The Bon Marche & 42 & $\$ 955$ million \\
Stern's & 25 & $\$ 838$ million \\
\hline
\end{tabular}

Source: Federated Department Stores (1999) 1999 Corporate Fact Book, Federated Department Stores, Cincinnati, $\mathrm{OH}$. 
Table 5 Federated Divisional Consolidations, 1982-1996

\begin{tabular}{|c|c|c|c|}
\hline Year & Divisions & New Division Name & Comments \\
\hline \multirow[t]{3}{*}{1982} & Rike's (Dayton) & & \\
\hline & & Shillito Rike's (Cincinnati) & \\
\hline & Snitito s (Cincinnati) & & \\
\hline \multirow[t]{3}{*}{1986} & $\begin{array}{l}\text { Shillito Rike's } \\
\text { (Cincinnati) }\end{array}$ & & \\
\hline & & Lazarus (Cincinnati) & \\
\hline & Lazarus (Columbus) & & \\
\hline \multirow[t]{3}{*}{1987} & Block (Indianapolis) & & Block acquired from Allied Stores \\
\hline & & Lazarus & \\
\hline & Lazarus & & \\
\hline \multirow[t]{3}{*}{1988} & Goldsmith's & & Memphis area retains Goldsmith's \\
\hline & & Rich's & \\
\hline & Rich's & & \\
\hline \multirow[t]{3}{*}{1992} & Abraham and Strauss & & \\
\hline & & Abraham and Strauss/Jordan Marsh & \\
\hline & & & \\
\hline \multirow[t]{3}{*}{1994} & Joseph Horne Co. & & Acquisition \\
\hline & & Lazarus & \\
\hline & Lazarus & & \\
\hline \multirow[t]{3}{*}{1994} & Macy's East & & Acquisition \\
\hline & & Macy’s East & \\
\hline & $\begin{array}{l}\text { Abranam and } \\
\text { Strauss/Jordan Marsh }\end{array}$ & & \\
\hline \multirow[t]{2}{*}{1995} & Rich/Goldsmith's & & \\
\hline & Lazarus & 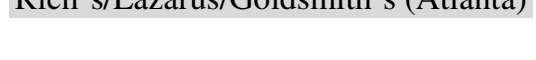 & \\
\hline 1995 & $\begin{array}{c}\text { Broadway (Broadway, } \\
\text { Emporium and } \\
\text { Weinstocks } \\
\text { nameplates) }\end{array}$ & $\begin{array}{l}5 \text { stores: Bloomingdale's } \\
56 \text { stores: Macy } \\
21 \text { stores sold }\end{array}$ & Acquisition of 82 stores \\
\hline 1996 & Jordan Marsh & Macy East & $\begin{array}{l}\text { Loses autonomy in Macy East } \\
\text { Division }\end{array}$ \\
\hline 1996 & Bullock's & Macy West & $\begin{array}{l}\text { Loses autonomy in Macy West } \\
\text { Division }\end{array}$ \\
\hline
\end{tabular}

Source: Various trade press literature and discussions with company executives 
Figure 3 Federated Department Stores Centralised Support Functions

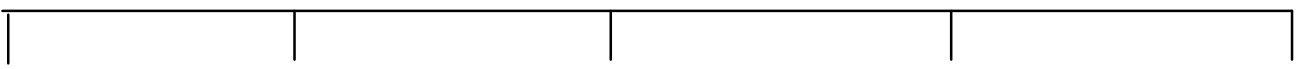

\begin{tabular}{|c|c|c|c|c|}
\hline $\begin{array}{l}\text { Financial and } \\
\text { Credit } \\
\text { Services } \\
\text { (FACS) Group }\end{array}$ & $\begin{array}{l}\text { Federated } \\
\text { Corporate }\end{array}$ & $\begin{array}{l}\text { Federated } \\
\text { Logistics and } \\
\text { Operations } \\
\text { (FLO) }\end{array}$ & $\begin{array}{c}\text { Federated } \\
\text { Merchandising } \\
\text { Group (FMG) }\end{array}$ & $\begin{array}{c}\text { Federated } \\
\text { Systems Group } \\
\text { (FSG) }\end{array}$ \\
\hline $\begin{array}{l}\text { Founded in } \\
1989 \text { to service } \\
\text { all private label } \\
\text { credit card } \\
\text { accounts on } \\
\text { behalf of FDS } \\
\text { National Bank } \\
\text { for each of the } \\
\text { company's } \\
\text { operating } \\
\text { divisions. }\end{array}$ & $\begin{array}{l}\text { Corporate office } \\
\text { supplies an } \\
\text { organisation of } \\
\text { professional } \\
\text { managers } \\
\text { providing } \\
\text { expertise to the } \\
\text { entire firm, } \\
\text { including } \\
\text { divisions and } \\
\text { support }\end{array}$ & $\begin{array}{l}\text { Created in 1994, } \\
\text { FLO } \\
\text { coordinates } \\
\text { merchandise } \\
\text { distribution, } \\
\text { logistics } \\
\text { functions and } \\
\text { vendor } \\
\text { technology } \\
\text { across the firm. }\end{array}$ & $\begin{array}{l}\text { Reconfigured } \\
\text { continually } \\
\text { throughout the } \\
\text { 1990s, FMG is } \\
\text { responsible for } \\
\text { the process of } \\
\text { conceptualising, } \\
\text { designing, } \\
\text { sourcing and } \\
\text { marketing private } \\
\text { label and private }\end{array}$ & $\begin{array}{l}\text { FSG offers an } \\
\text { integrated line } \\
\text { of central } \\
\text { merchandising, } \\
\text { inventory, sales, } \\
\text { operations and } \\
\text { distribution, } \\
\text { financing and } \\
\text { human resource } \\
\text { management } \\
\text { software. These }\end{array}$ \\
\hline & $\begin{array}{l}\text { operations } \\
\text { worldwide. }\end{array}$ & & $\begin{array}{l}\text { branded goods } \\
\text { across all } \\
\text { divisions, except } \\
\text { Bloomingdale's } \\
\text { and Stern's. Also } \\
\text { responsible for } \\
\text { managing core } \\
\text { vendor } \\
\text { relationships. }\end{array}$ & $\begin{array}{l}\text { services } \\
\text { facilitate } \\
\text { management's } \\
\text { ability to } \\
\text { monitor the } \\
\text { effectiveness of } \\
\text { the company's } \\
\text { strategies on a } \\
\text { consolidated } \\
\text { basis. }\end{array}$ \\
\hline
\end{tabular}

Source: Company Information 
Table 6 Stages in the reconfiguration of Federated Logistics and Operations (FLO)

\begin{tabular}{l|l}
\hline $\boldsymbol{D A T E}$ & COMMENTS \\
\hline 1994 & $\begin{array}{l}\text { Federated Merchandising set up to co-ordinate merchandise distribution and } \\
\text { logistics functions and vendor technology across the company, with particular } \\
\text { emphasis on the north-eastern U.S. }\end{array}$ \\
1995 & $\begin{array}{l}\text { Division expanded to handle these functions for all of Federated divisions } \\
\text { nationwide }\end{array}$ \\
$\begin{array}{l}\text { Division's scope expanded again to assume corporate responsibility for key } \\
\text { operational areas of the business including expense control, energy } \\
\text { management, asset recovery, accounts payable, purchasing, loss prevention, } \\
\text { shortage control, leased departments and maintenance functions. }\end{array}$ \\
\hline
\end{tabular}

Source: Company Information

Table 7 Centralised Functional Integration versus Decentralised Business Unit Integration

\begin{tabular}{|c|c|c|c|}
\hline & Organising Principle & Advantages & Disadvantages \\
\hline $\begin{array}{l}\text { Functional integration } \\
\text { (Centralised) }\end{array}$ & $\begin{array}{l}\text { - Organise functionally to } \\
\text { achieve cost and skill } \\
\text { advantages of scale }\end{array}$ & $\begin{array}{l}\text { - Economies of scale in } \\
\text { distribution, Advertising, } \\
\text { Infrastructure } \\
\text { - Builds functional skill } \\
\text { superiority } \\
\text { - Information can be } \\
\text { leveraged across the } \\
\text { whole organisation }\end{array}$ & $\begin{array}{l}\text { - Lack of responsiveness } \\
\text { to local requirements } \\
\text { - Difficult to develop } \\
\text { general managers } \\
\text { - Expense of 'expert } \\
\text { systems' } \\
\text { - Vendor intensification } \\
\text { may result in too much } \\
\text { homogeneity in } \\
\text { assortment } \\
\text { - New products from } \\
\text { smaller vendors often } \\
\text { overlooked } \\
\text { - Possible lack of } \\
\text { accountability at a } \\
\text { distance }\end{array}$ \\
\hline $\begin{array}{c}\text { Business unit } \\
\text { integration } \\
\text { (Decentralised) }\end{array}$ & $\begin{array}{l}\text { - Organize around } \\
\text { multiple profit centres to } \\
\text { gain advantage of focus }\end{array}$ & $\begin{array}{l}\text { - Focus/clear } \\
\text { accountability } \\
\text { - Close to customer = } \\
\text { responsiveness } \\
\text { - Builds teams/identities }\end{array}$ & $\begin{array}{l}\text { - Lack of scale } \\
\text { - Duplication of effort } \\
\text { - No critical mass of skills }\end{array}$ \\
\hline
\end{tabular}

Source: adapted from George et al., 1994, p55 
Figure 4 Geographies of Organisation of the Late 20th Century Department Store

\section{CORE COMPETANCIES - HEADQUARTERS}

- Strategic Direction

- Funding

- Back Office Facilities

- Credit Services

- Logistics and Operations Technology

- Systems Group

- Corporate Services
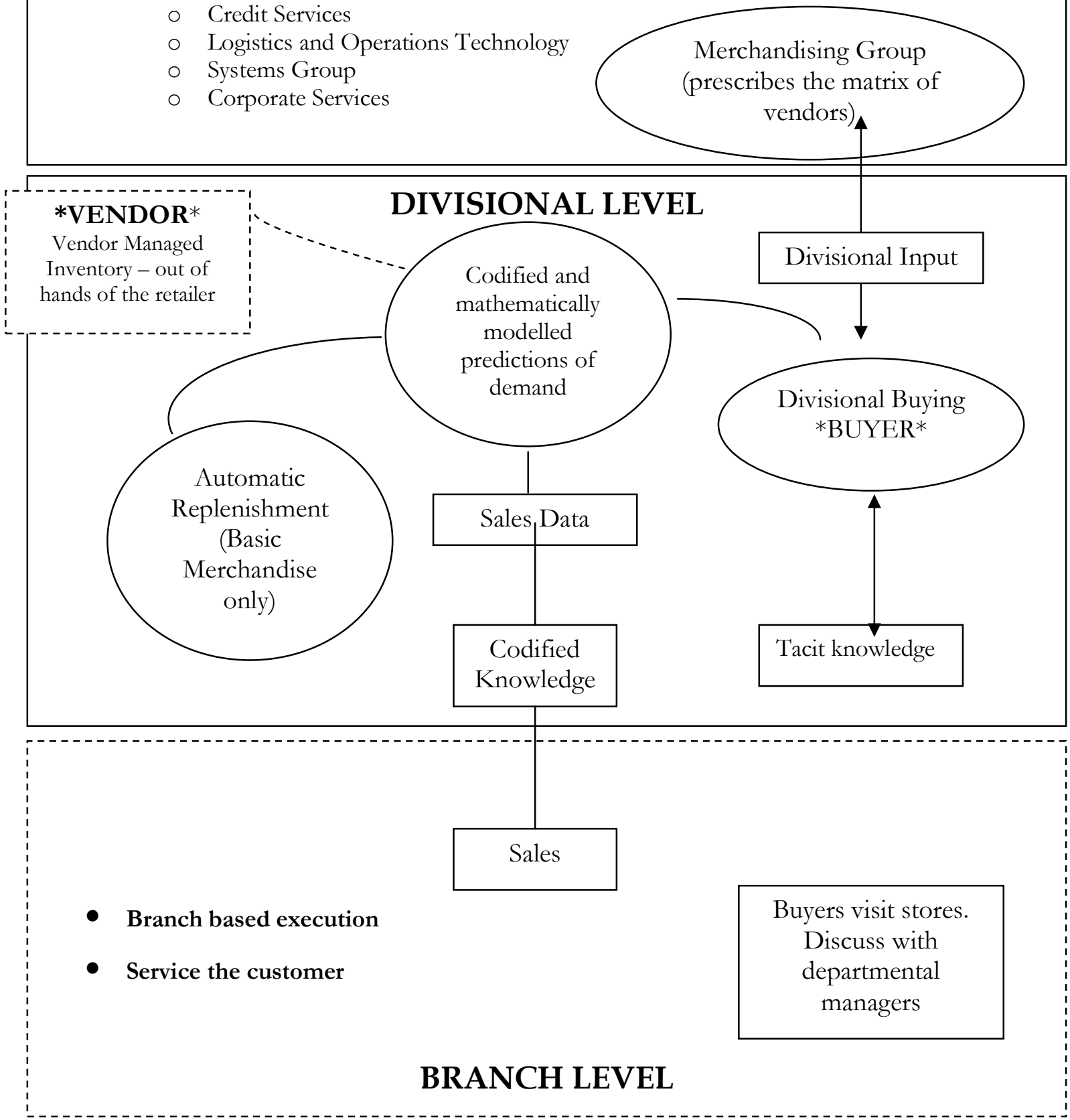